\title{
Privatization versus Private Sector Initial Public Offerings in Poland*
}

\author{
Wolfgang Aussenegg \\ Vienna University of Technology, Austria
}

This article compares the characteristics and the price behavior of case-bycase privatization initial public offerings and private sector initial public offerings in Poland over the first nine years after the reopening of the Warsaw Stock Exchange in April 1991. There is evidence that the Polish government is market-oriented, trying to build up reputation for its privatization policy over time by underpricing, selling a high fraction at the initial offer and underpricing more when selling to domestic retail investors. In the long run privatization initial public offerings experience neither an under- nor an overperformance. A lower political influence has no effect on the long-run performance of privatized companies (JEL G12, G18, G38).

Keywords: initial public offerings, long-run performance, privatization, underpricing.

\section{Introduction}

This article examines the characteristics as well as the short- and longrun price behavior of Polish case-by-case privatization initial public offerings (PIPOs) compared to Polish private sector IPOs (IPOs). More specifically, we analyze the following questions: First, how do PIPOs

*I am grateful to Adam Gehr, Alois Geyer, George Papaioannou, Enrico Perotti, Hans Reitbauer, Christian Schlag, Peter Theodossiou (the managing editor), Helmut Uhlir, Pieter van Oijen, David Walker, Anja Wodrich, the editor-in-charge, two anonymous referees, participants of the 1999 Conference on Equity Market Development in Emerging and Transition Economies (Amsterdam, December 1999), the 2000 Midwest Finance Association meeting (Chicago, April 2000), the 2000 Financial Management Association European Conference (Edinburgh, May 2000) and the ABN-AMRO Conference on Initial Public Offerings (Amsterdam, July 2000) for helpful comments and suggestions. Financial support of the Vienna University of Technology in acquiring data used in this study is gratefully acknowledged. The author would also like to thank Reuters Ges.m.b.H (Vienna) for providing data.

(Multinational Finance Journal, 2000, vol. 4, no. 1\&2, pp. 69-99)

CMultinational Finance Society, a nonprofit corporation. All rights reserved.

DOI: $10.17578 / 4-1 / 2-4$ 
and private sector IPOs differ with respect to underpricing? Second, how can the underpricing of PIPOs and private sector IPOs be explained? Third, do Polish PIPOs experience a positive long-run performance? Fourth, how does the long-run performance of Polish PIPOs compare to private sector IPOs and how does the fraction sold affect the long-run performance of PIPOs?

This aritcle contributes to the existing literature in several ways: First, an Eastern European emerging market is examined completely from the resumption of the stock market. Other studies, like Jones et al. (1999), Megginson et al. (2000), Dewenter and Malatesta (1997) or Huang and Levich (1998) investigate several markets all over the world and consider developed and emerging markets jointly. The analysis of a single (Eastern European) emerging market can provide additional insights as the database is more homogeneous. Second, the investigation of a share privatization program right from the beginning allows testing to what extent a build-up of reputation for the government concerning the privatization program takes place over time. Third, in addition to PIPOs private sector IPOs are also examined and both groups are compared to each other. This allows identifying similarities and differences between privatization and private sector IPOs concerning their characteristics as well as their short- and long-run price performance. ${ }^{1}$

The following section reviews the empirical evidence of studies examining the price performance of PIPOs and presents testable hypotheses about the short- and long-run price behavior of PIPOs and private sector IPOs. Section three describes the database used and provides descriptive statistics for the IPO groups. In the fourth section the empirical evidence regarding the initial return is presented and possible reasons for the underpricing are examined. Section five deals with the aftermarket performance and section six gives a summary of the findings.

1. There have only been a few comparisons of this kind in the literature. Examples are Menyah and Paudyal (1996), who examine privatization and private sector IPOs for the UK; Paudyal, Saadouni, and Briston (1998), who compare these groups for Malaysia; and Jelic and Briston (1999), who analyze the price behavior of Hungarian privatizations and private sector IPOs. The studies of Dewenter and Malatesta (1997) and Huang and Levich (1998) also compare privatization and private sector IPOs but they only analyze the underpricing. 


\section{Literature Review and Testable Hypotheses}

\section{A. The underpricing of PIPOs and IPOs}

Numerous studies focusing on privately-owned unseasoned new issues document two main phenomena: First, firms going public are underpriced and second, they tend to underperform benchmark firms in the long run. ${ }^{2}$ Studies analyzing the price behavior of privatized state-owned enterprises show that PIPOs are, on average, also underpriced. One of the first studies in this context was carried out by Jenkinson and Mayer (1988) for French and UK IPOs. Other studies are for example Perotti and Guney (1993), Dewenter and Malatesta $(1997)^{3}$, Huang and Levich (1998) and recently Jones et al. (1999) who examine a 59-country sample of PIPOs for which they document an average initial return of $34.1 \% .{ }^{4}$ A significantly positive underpricing can also be observed for Hungarian PIPOs (see Jelic and Briston (1999)).

Studies explicitly comparing the characteristics and the price behavior of PIPOs and private sector IPOs are scarce. For a 7-country sample (Canada, France, Hungary, Japan, Malaysia, Thailand, and the UK) Dewenter and Malatesta (1997) find no general tendency for privatizations to be underpriced more than private sector IPOs. Similar results are provided by Jelic and Briston (1999) for Hungary. In contrast, Paudyal, Saadouni, and Briston (1998) report that the average initial return on Malaysian PIPOs is significantly higher than on private sector IPOs. $^{5}$

Many theories have been put forward to explain the underpricing of initial public offerings. In order to formulate hypotheses to explain the first-day return level of Polish PIPOs and private sector IPOs, the most common and for Poland most relevant testable explanations will be examined.

Asymmetric information theories imply that the uncertainty about the

2. See for example Loughran, Ritter, and Rydqvist (1994) for a survey reviewing the international empirical evidence.

3. For a subsample of 19 Polish PIPOs they document a mean market-adjusted initial return of $50.0 \%$.

4. Their 59-country sample consists of 242 privatization initial public offerings (PIPOs), with 26 PIPOs in the Polish subsample.

5. An extensive survey of empirical studies on privatizations are provided by Megginson and Netter (2000). 
value of smaller, not established firms is higher than that of larger, wellknown firms. As larger firms are better known to investors, they should be easier to value and, hence experience a lower initial market-adjusted return. As PIPOs tend to be larger than private sector IPOs this hypothesis also suggests that initial returns in PIPOs should be lower than initial returns in private sector IPOs. We test the following hypotheses:

Hypothesis 1: Ex-ante uncertainty I: The initial market-adjusted return of PIPOs is lower than for private sector IPOs.

Hypothesis 2: Ex-ante uncertainty II: The initial market-adjusted return of large firms is lower than for small firms.

Allen and Faulhaber (1989), Grinblatt and Hwang (1989), and Welch (1989) assume that issuers possess better information about the true value of the offer than investors. In these (pure) signaling models, highquality firms sell a low fraction of the share capital at the initial offer and deliberately choose an offer price below the intrinsic value to signal their quality to investors. This underpricing is motivated by the possibility of achieving higher offer prices in subsequent seasoned issues. We test the following hypothesis:

Hypothesis 3: Pure signaling: High-quality firms will underprice their issues and only offer a small part of their share capital at the initial issue. This implies a negative relationship between the initial market-adjusted return and the fraction of the share capital sold at the initial offer.

Perotti's (1995) model assumes that there is informational asymmetry between the privatizing government and the investors. He distinguishes between two types of governments: market-oriented (committed) and populist governments. A market-oriented government wants to privatize state-owned enterprises seriously and irreversibly. This does not apply to populist governments. Privatization can only restrain but not eliminate public interference, for example to transfer value from shareholders to other groups by policy changes through regulation or taxation. A government committed to privatization will not use such instruments to transfer value, but less committed or populist governments will.

At the beginning of a privatization program the political uncertainty 
can be expected to be highest and a committed government might be forced to sell a higher fraction at the initial offer to signal the willingness to give up control rights. To convince the market to absorb a large portion and to signal commitment, a government will have to underprice. In the case of a market-oriented government, it can be expected that the political uncertainty will drop over time as the buildup of reputation occurs. This has the testable implication that for a committed government the fraction of PIPOs sold at the initial offer should be higher at the beginning of the privatization program. The same expectation holds for the underpricing of PIPOs. In this context we test the following hypothesis:

Hypothesis 4: Political Uncertainty: If a large fraction of the share capital is sold at the beginning of the privatization program to signal the willingness to give up control rights, a committed government has to underprice more. For such a government, the underpricing is expected to be highest at the beginning of the process and to drop (in line with the fraction sold) as reputation builds up.

Biais and Perotti (2000) show that a market-oriented government can generate support for its privatization program by allocating more shares to median-class voters. Since a reversal of the privatization program decreases the value of the already privatized firms, median-class voters will support the privatization efforts of the government, which results in a support of the government in elections (re-election hypothesis). In order to make median-class voters buy enough shares so that their political preferences are similar to those of the government, underpricing is necessary. A government can achieve this aim by allocating a large portion to domestic retail investors (median-class voters). We test the following hypothesis:

Hypothesis 5: Re-Election: The relationship between the initial market-adjusted return and the portion of the issue volume allocated to domestic retail investors is positive.

\section{B. The Long-Run Performance of PIPOs and IPOs}

The empirical evidence of the long-run performance of firms going public indicates that PIPOs and private sector IPOs do not perform similarly. Private sector IPOs mostly experience a negative abnormal 
performance over the first three to five years of aftermarket trading, ${ }^{6}$ whereas PIPOs mostly experience a long-run aftermarket performance equal or better than that of benchmark firms. For example, Megginson et al. (2000) document for a 33-country sample of privatizations a significantly positive aftermarket performance regardless of the benchmark used. Menyah and Paudyal (1996) report similar results for a sample of UK PIPOs and Jelic and Briston (1999) for Hungarian PIPOs. A long-run performance equal to benchmark firms is documented by Paudyal, Saadouni, and Briston (1998) for Malaysia while Boubakri and Cosset (1999) document, for 120 PIPOs from 26 developing countries, a positive performance relative to benchmark firms and no abnormal performance relative to the market index.

While Jelic and Briston (1999) report that Hungarian PIPOs significantly outperform their private sector counterparts in the long run, Paudyal, Saadouni, and Briston (1998) document no abnormal long-run aftermarket performance difference between privatizations and private sector IPOs in Malaysia.

A non-negative long-run abnormal performance for PIPOs coincides with the objectives of a market-oriented government. As privatization programs in most cases last several years, a committed government will be interested in building up reputation for its privatization program over time by establishing a market-oriented economic environment. This will support the restructuring activities of newly privatized firms and therefore should generate a positive effect on the long term stock market performance of PIPOs. We test the following hypothesis for Polish privatizations:

Hypothesis 6: The long-run aftermarket performance from the first trading day till the third-year anniversary is non-negative for Polish PIPOs.

Going public is a one time event for a private sector firm and their managers/owners whereas for the government, going public is a continuous event as it sells many firms in the course of time. A committed government will therefore be interested in a good long-run performance in order to attract investors for future issues. In contrast,

6. See for example Ritter (1991) and Loughran and Ritter (1995) for US IPOs, Levis (1993) for UK IPOs or Keloharju (1993) for Finnish IPOs. 
the managers/owners of private sector issuing firms have rather shortterm objectives, that is of maximizing the issue proceeds. This conjecture is supported by the empirical observation that managers/owners appear to time their issues after large stock market increases (see for example Ritter (1991)). We therefore test whether the long-run abnormal performance of Polish PIPOs significantly exceeds that of Polish private sector IPOs:

Hypothesis 7: The long-run abnormal performance from the first trading day till the third-year anniversary is significantly better for PIPOs than for private sector IPOs.

Boycko, Shleifer, and Vishny (1996) show in their model that the fraction a government sells at the initial offer is an important factor for the restructuring efforts of state enterprises. The higher is the fraction sold, the lower is the possibility that politicians interfere directly. Boycko, Shleifer, and Vishny (1996) conclude that the relationship between restructuring activities and the fraction of the state enterprise sold at the initial offer should be positive. Provided that a lower state holding leads to a better restructuring, the long-run abnormal performance should be positively associated to the fraction sold. In this context the following hypothesis is tested:

Hypothesis 8: Political Influence: The higher the fraction of the share capital sold at the initial offer, the lower is the direct political influence. This implies more efficient restructuring and therefore a superior long-run abnormal performance compared to issues from which the state sells a lower fraction.

\section{Data and Sample Characteristics}

The Warsaw Stock Exchange (WSE) was founded in 1817. During the Second World War and the following decades of communism the WSE was closed. The WSE resumed trading on April 16, 1991 with the listing of five firms. From April 1991 till the end of 1999 altogether 215 firms went public with a listing on the WSE. During this period 107 firms started trading in the main market of the WSE, 78 in the parallel market and 30 in the free market. At the end of 1999, 206 firms were listed on the WSE: 119 in the main market, 61 in the parallel market and 26 in the 
free market. ${ }^{7}$ The parallel market started on April 22, 1993 and the free market on February 20, 1997.

This study uses the two biggest market segments of the WSE: the main market and the parallel market. They comprise the biggest and most liquid firms trading on the WSE. Disclosure requirements are the same for all companies, regardless of their quotation market. All companies are quoted in the single-price auction system. In addition, shares of the most liquid companies from the main and the parallel markets are traded in the continuous trading system. The main market and the parallel market differ with respect to the listing requirements. A company wishing to begin trading in the main market has to satisfy higher minimum size and liquidity criteria than a company applying for listing on the parallel market. ${ }^{8}$

The investigation period starts with the reopening of the WSE on April 16, 1991 and ends on December 31, 1999. Of the 185 firms going public in the main and the parallel market, respectively, we only use those offers that (a) made a public offer before trading on the WSE and (b) have all the necessary information (especially issue price, issue volume, demand multiple, contract type (fixed price or tender), dividend payment and seasoned equity offering information). Therefore, the final sample comprises 159 firms, 99 from the main market and 60 from the parallel market. For investigation purposes, the sample of 159 firms is divided into two groups: A sample of 52 PIPOs and a sample of 107 private sector IPOs..$^{9}$ In the sample of PIPOs, all those firms are included which are classified as Public Offering by State Treasury in the WSE Fact Book 2000. These are firms controlled by the Polish state

7. The differences to the number of going publics can be explained by changes from one market segment to another and nine delistings. To avoid a delisting bias all delisted firms are included in this study.

8. Examples of listing requirements (PLN numbers valid in the years 1998 and 1999) are the minimum value of shares to be admitted for trading (PLN 40 mil. for the main market versus PLN 14 mil. for the parallel market), the minimum book value of the company (PLN 65 mil. versus PLN 22 mil.), the minimum number of shareholders who hold shares to be admitted for trading (500 versus 300) and the period for which the company is required to disclose audited financial reports to the public (three financial years for the main market versus two financial years for the parallel market).

9. Of the 52 PIPOs 50 went public in the main market and 2 in the parallel market. Of the 107 private sector IPOs 49 went public in the main market and 58 in the parallel market. 
TABLE 1. Number of Issues Per Year

\begin{tabular}{lrrr}
\hline Year & All & PIPOs & IPOs \\
\hline 1991 & 9 & 9 & 0 \\
1992 & 5 & 5 & 0 \\
1993 & 6 & 4 & 2 \\
1994 & 20 & 8 & 12 \\
1995 & 21 & 8 & 13 \\
1996 & 17 & 3 & 14 \\
1997 & 39 & 10 & 29 \\
1998 & 37 & 4 & 33 \\
1999 & 5 & 1 & 4 \\
Total & 159 & 52 & 107 \\
\hline
\end{tabular}

Note: Number of issues per year for the samples: all issues (All), privatization IPOs (PIPOs) and private sector IPOs (IPOs).

and for most of them $100 \%$ of the shares were held by the state prior to the issue. Table 1 reports for the sample of PIPOs and IPOs as well as the total sample the number of issues per year.

To build up the database three main sources were used. First, the Historical Database of the Warsaw Stock Exchange, which provides information on daily stock prices, dividend payments, number of outstanding shares and the first trading day on the WSE. Second, several editions of the WSE Fact Book were utilized to get information about issue prices, first trading day, original ownership structure of listed companies, dividend payments, stock splits, mergers and delistings. Finally, information on subscription period, issue price, ownership structure, demand multiple, share allocation, gross proceeds, seasoned equity offerings, stock splits and other company-related information was obtained from REUTERS Business Briefing Archives. All information received from these three main sources was checked and completed using information available for the Polish stock market in Reuters 3000 Equities History as well as in Datastream.

Table 2 presents summary statistics for the sample of all 159 issues (All), the 52 PIPOs and the sample of 107 private sector IPOs (IPOs). About $84.5 \%$ of the total gross proceeds of 18,843 million PLN comes from the 52 PIPOs (15,932 million PLN). The mean (median) gross proceeds for the PIPO firms are more than 11 (3) times higher than for 
the private sector IPOs (306.4 versus 27.2 million PLN and 43.5 versus 14.4 million PLN). The mean as well as the median gross proceeds are significantly different from each other (see table 2, panel B). This has two reasons: First, PIPO firms are larger than private sector IPOs, and second, the fraction sold at the initial offer is nearly twice as high for the PIPO firms as for private sector IPOs (63.2\% versus $32.1 \%)$. The two samples significantly differ from each other in this respect. The mean percentage of capital offered in the 59-country sample of PIPOs in Jones et al. (1999) is 43.9\%. Therefore, the Polish government sold about 19 percentage points (or $45 \%$ ) more than the average fraction sold on a global basis. ${ }^{10}$

PIPOs and private sector IPOs not only differ with respect to the gross proceeds and the fraction sold at the initial offer but also significantly depending on whether secondary or primary shares are sold. Of the gross proceeds for PIPO firms, $94.4 \%$ consist of secondary shares and two thirds of PIPOs sold exclusively secondary shares. In contrast, only primary shares were sold at the initial offer in $84.1 \%$ of private sector IPOs. This observation is consistent with the evidence provided by Megginson, Nash, and Van Randenborgh (1994) and Jones et al. (1999) that PIPOs in most cases tend to be pure secondary offerings with none of the sale proceeds flowing to the firm. On the other hand, private sector IPOs tend to be mostly primary, capital-raising events. As the evidence for Poland shows, this seems to be a general feature of private sector IPOs.

The empirical evidence for Poland reveals that only $57.7 \%$ of all PIPOs in the sample have a fixed issue price. This compares to the global evidence in Jones et al. (1999) of 79.9\% fixed-price offers for their 59-country sample. This indicates that the Polish government did not excessively need fixed-price offers to generate enough demand for its issues. The average demand measured by the demand multiple is only a little higher for PIPOs than for the private sector IPOs (2.63 versus 1.96). ${ }^{11}$ But both mean and median demand multiples of the two samples

10. For Non-UK PIPOs, Jones et al. (1999) document an average fraction sold at the initial offer of only $37.9 \%$. Similar results can be found in Huang and Levich (1998).

11. Much higher demand multiples are reported for Malaysia, with mean demand multiples of 21.2 for PIPOs and 23.4 for private sector IPOs (see Paudyal, Saadouni, and Briston (1998)). 
TABLE 2. Sample Characteristics

\begin{tabular}{|c|c|c|c|}
\hline A. Summary Statistics & All & PIPOs & IPOs \\
\hline Number of firms & 159 & 52 & 107 \\
\hline \multicolumn{4}{|l|}{ Gross proceeds: } \\
\hline Total (million PLN) & $18,843.4$ & $15,931.7$ & $2,911.8$ \\
\hline Primary shares (million PLN) & $3,514.1$ & 890.9 & $2,623.2$ \\
\hline Secondary shares (million PLN) & $15,329.3$ & $15,040.8$ & 288.6 \\
\hline Primary shares $(\%)$ & 18.65 & 5.59 & 90.09 \\
\hline Secondary shares $(\%)$ & 81.35 & 94.41 & 9.91 \\
\hline Mean (million PLN) & 118.5 & 306.4 & 27.2 \\
\hline Median (million PLN) & 18.2 & 43.5 & 14.4 \\
\hline Percent of capital sold in offer & 42.28 & 63.25 & 32.08 \\
\hline \multicolumn{4}{|l|}{ Portion of issues: } \\
\hline only secondary shares (\%) & 28.9 & 67.3 & 10.3 \\
\hline only primary shares $(\%)$ & 57.9 & 3.8 & 84.1 \\
\hline fixed-price offers (\%) & 67.3 & 57.7 & 72.0 \\
\hline tender offers $(\%)$ & 32.7 & 42.3 & 28.0 \\
\hline Mean demand multiple & 2.18 & 2.63 & 1.96 \\
\hline $\begin{array}{l}\text { Mean fraction sold to employees } \\
\text { at initial offer }(\%)\end{array}$ & 9.72 & 19.02 & 5.20 \\
\hline \multicolumn{2}{|c|}{ B. PIPOs and Private Sector IPOs Differences } & Mean & Median \\
\hline \multirow{2}{*}{\multicolumn{2}{|c|}{ Gross proceeds (million PLN) }} & $277.17 *$ & $29.10 *$ \\
\hline & & $(3.00)$ & $(4.57)$ \\
\hline \multirow{2}{*}{\multicolumn{2}{|c|}{ Percent of capital sold in offer }} & $31.17 *$ & $36.08 *$ \\
\hline & & $(6.82)$ & $(5.97)$ \\
\hline \multirow{2}{*}{\multicolumn{2}{|c|}{ Portion of issues: only secondary shares $(\%)$}} & $57.10^{*}$ & $100.00 *$ \\
\hline & & $(7.92)$ & $(5.82)$ \\
\hline \multirow{2}{*}{\multicolumn{2}{|c|}{ Portion of issues: only primary shares $(\%)$}} & $-80.30 *$ & $-100.00 *$ \\
\hline & & $(-18.01)$ & $(-8.20)$ \\
\hline \multirow{2}{*}{\multicolumn{2}{|c|}{ Demand multiple }} & 0.67 & -0.03 \\
\hline & & $(1.32)$ & $(1.25)$ \\
\hline \multirow{2}{*}{\multicolumn{2}{|c|}{ Fraction sold to employees at the initial offer (\%) }} & $13.82 *$ & $18.68^{*}$ \\
\hline & & $(4.92)$ & $(5.58)$ \\
\hline
\end{tabular}

Note: Summary statistics (period: April 1991 to December 1999) for the samples: all issues (All), privatization IPOs (PIPOs) and private sector IPOs (IPOs) as well as mean and median differences between PIPOs and private sector IPOs (PIPOs minus IPOs) for several characteristics. In panel B it is tested whether (a) the differences in the mean and (b) the differences in the median values are significantly different from zero. For the means a $t$-test and for the medians a Wilcoxon-Signed-Rank-Test is used. Test statistics in parentheses. $*$ Significant at the $1 \%$ level. 
are not significantly different from each other.

In Poland trade unions have historically been very powerful. In the process of privatization it can therefore be expected that the government will particularly try to offer shares to the employees of the state enterprises. On average (median) $19.0 \%$ (18.7\%) of the shares sold during the initial offer were offered to employees. This value is more than twice as high as the international evidence in Jones et al. (1999). For their 59-country sample they report an average (median) portion sold to employees of $8.5 \%$ (7.0\%). ${ }^{12}$ This underlines the strong and important position of trade unions in Poland and the political necessity to integrate Polish employees in the privatization program to a higher degree than in most other countries.

\section{Tests for Initial Returns}

\section{A. Methodology and Summary Statistics}

The starting point in investigating the initial returns is the calculation of initial raw returns and initial market-adjusted returns. The initial raw return for IPO $i$ corresponds to its buy-and-hold return $(B H R)$ from the issue price to the closing price on the first trading day and is defined as

$$
B H R_{i}=\frac{P_{i, 1}-P_{i, 0}}{P_{i, 0}}
$$

where $P_{i, 0}$ represents the issue price and $P_{i, 1}$ the closing price on the first trading day of IPO $i$. The time index $t=0$ refers to the first day of the subscription period. The market-adjusted return for each issue is defined as the difference between its initial raw return (the $B H R_{i}$ ) and the corresponding return on the market index:

$$
I R_{i}=B H R_{i}-B H R_{W I G, i},
$$

where $I R_{i}$ is the initial market-adjusted return of IPO $i$ and $B H R_{W I G, i}$ is

12. For an international sample of 190 PIPOs Huang and Levich (1998) document an average portion sold to employees of $9.5 \%$. 
the buy-and-hold return of the Warsaw Stock Exchange Index $(W I G) .{ }^{13}$ Analogous to (1) the $B H R$ for the $W I G$-Index is defined as

$$
B H R_{W I G, i}=\frac{W I G_{i, 1}-W I G_{i, 0}}{W I G_{i, 0}} .
$$

$W I G_{i, 0}$ represents the WIG-Index on the first day of the subscription period of IPO $i$ and $W I G_{i, 1}$ is the WIG-Index at the end of the first trading day of IPO $i$.

Panel A of table 3 presents summary statistics of the raw and market-adjusted initial returns for all three samples. By investing an equal amount of money in each of the 159 Polish IPOs at the issue price and selling each IPO on its first trading day an investor would have earned an average initial raw return of $+38.5 \%$. Applied to the individual subsamples this trading strategy would have yielded average initial raw returns of $+65.6 \%$ and $+25.3 \%$ for the PIPOs and the private sector IPOs, respectively. The market-adjusted average initial returns are also all positive: $60.4 \%$ for PIPOs, $19.8 \%$ for private sector IPOs and $33.1 \%$ for the sample of all 159 issues. All mean and median returns reported in panel A of table 3 are significantly greater than zero at the $1 \%$ significance level. In addition, about a quarter of all 159 issues are overpriced (negative initial market-adjusted return). These results document that, similar to the findings reported in earlier research for other markets, Polish PIPOs as well as Polish private sector IPOs are significantly underpriced.

This evidence is in line with the findings reported in Dewenter and Malatesta (1997). They test the hypothesis that the mean initial return in PIPOs equals the mean initial return in IPOs of privately-owned companies for Canada, France, Hungary, Japan, Malaysia, Thailand, and the United Kingdom. While their test indicates mixed results for individual countries, they are not able to reject the hypothesis that mean initial returns of PIPOs and IPOs of privately-owned companies differ for their joint sample of seven countries.

For a 59-country sample of 303 PIPOs Jones et al. (1999) present an average (median) initial raw return of $34.1 \%$ (12.4\%). The average

13. The WIG is a value-weighted share price index comprising all firms listed on the main market of the Warsaw Stock Exchange. 


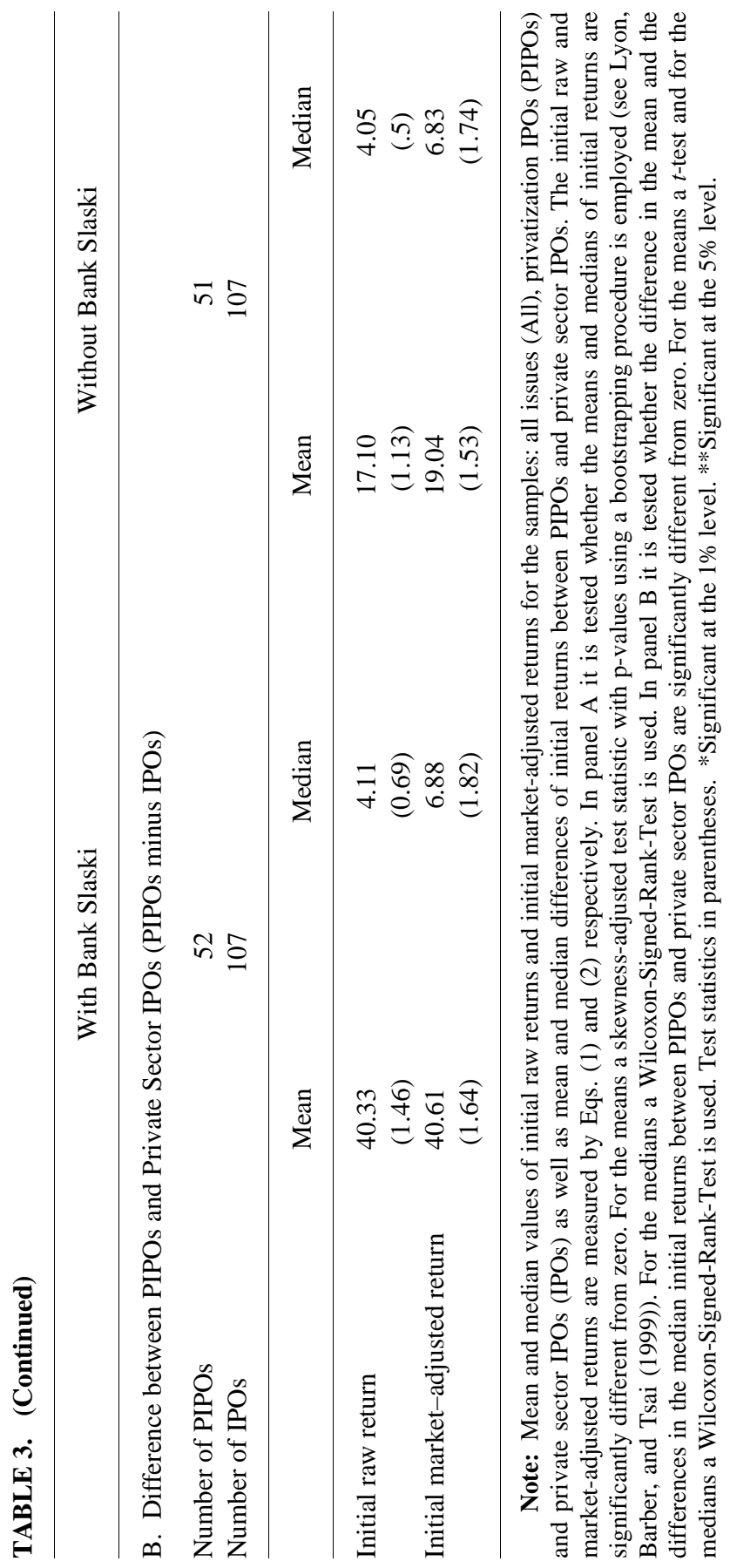


initial raw return for Polish PIPOs is therefore nearly twice as high. Only two studies examining individual countries report a higher underpricing for PIPOs compared to Poland: Paudyal, Saadouni, and Briston (1998) for Malaysia (103.5\%) and Su and Fleisher (1999) for China (948.6\%). A lower underpricing is documented for Chile (7.6\%, Aggarwal, Leal, and Hernandez (1993)), for Hungary (44\%, Jelic and Briston (1999), for the UK (38.7\%, Menyah and Paudyal (1998) and France (25.1\%, Jenkinson and Mayer (1988). The observation that the Polish government sold a higher fraction at the initial offer than the average reported for Jones' 59-country sample is consistent with the predictions in Perotti (1995). A market-oriented government selling a higher fraction at the initial offer has to underprice more to signal its commitment.

The mean raw and market-adjusted initial returns of PIPOs are about 40 percentage points above those of private sector IPOs (see table 3, panel B). But both test statistics of 1.46 and 1.64 are statistically insignificant. The differences in the median values are only $+4.1 \%$ and $+6.9 \%$. The main reason for the large mean underpricing of PIPOs is one issue: Bank Slaski. ${ }^{14}$ Without Bank Slaski the average (median) initial market-adjusted return of the remaining 50 PIPOs drops to $+38.9 \%(+19.7 \%)$, resulting in a decreased and statistically insignificant average (median) difference between PIPOs and private sector IPOs of $19.0 \%(6.8 \%)$. Altogether this indicates that the Polish government does not significantly underprice initial offers more than private company issuers do. Hypothesis 1, which implies that the initial market-adjusted return of PIPOs is lower than for private sector IPOs, therefore has to be rejected.

According to hypothesis 4, a committed government has to underprice more to signal the willingness to give up control rights if a large fraction of the share capital is sold at the beginning of the privatization program (when the political uncertainty is expected to be highest). Assuming that the political uncertainty was high at the start of the program in Poland, the fraction sold and the initial market-adjusted return should have been highest at the beginning of the program and should have decreased over time due to the build up of reputation. To

14. After an issue price of 50 PLN the market price on the first trading day rose to 675 PLN. The resulting initial raw return of $+1,250 \%$ caused a lot of criticism for the privatization policy and led to the resignation of the deputy finance minister. 
analyze these hypotheses the investigation period is split into two equal sub-periods for earlier and later issues: April 1991 till August 1995 (subperiod I) and September 1995 till December 1999 (sub-period II).

Table 4 reports the empirical results. First, as expected, the fraction of capital sold at the initial offer is highest for PIPOs at the beginning of the program and decreases in the course of time (see panel A of table 4). The average (median) fraction sold is $71.5 \%$ (84.0\%) in the first subperiod and $51.1 \%(50.7 \%)$ in the second sub-period. Second, the average initial market-adjusted return of PIPOs is higher for earlier privatizations (sub-period I: 80.8\%) compared to later privatizations (subperiod II: $30.3 \%$ ), whereas the median values remain unchanged $(19.8 \%$ in the first versus $19.7 \%$ in the second sub-period).

The high average underpricing for earlier privatizations is caused by several PIPOs underpriced by more than $100 \%$. Among them is outlier Bank Slaski with an underpricing of $1166.8 \%$. Without Bank Slaski the average initial market-adjusted return level of PIPOs drops to $44.8 \%$, but is still higher than for later privatizations. The results in table 4 provide therefore some evidence for a committed (at least no populist) government in the sense of Perotti (1995).

The initial market-adjusted return for private sector IPOs and the fraction sold at the initial offer do not behave in the same way as for PIPOs. Throughout the period we consider, the fraction sold is nearly constant at around $30 \%$ and the average initial market-adjusted return decreases, whereas the corresponding median value increases.

\section{B. Multivariate Cross-Sectional Analysis}

We examine the determinants of the initial market-adjusted returns in Polish PIPOs and Polish private sector IPOs in a multivariate crosssectional analysis, thereby testing the remaining hypotheses specified in section two. The following regression model is used:

$$
I R_{i}=\alpha_{0}+\alpha_{1} \operatorname{SOLD}_{i}+\alpha_{2} \text { RETAIL }_{i}+\alpha_{3} \operatorname{SIZE}_{i}+\varepsilon_{i},
$$

where $I R_{i}=$ initial market-adjusted return of issue $i ; S O L D_{i}=$ fraction of the share capital sold at the initial offer (hypothesis 3: pure signaling); RETAIL $_{i}=$ relative portion domestic retail investors receive from the issue volume (hypothesis 5: re-election); $S I Z E_{i}=$ logarithmic market 


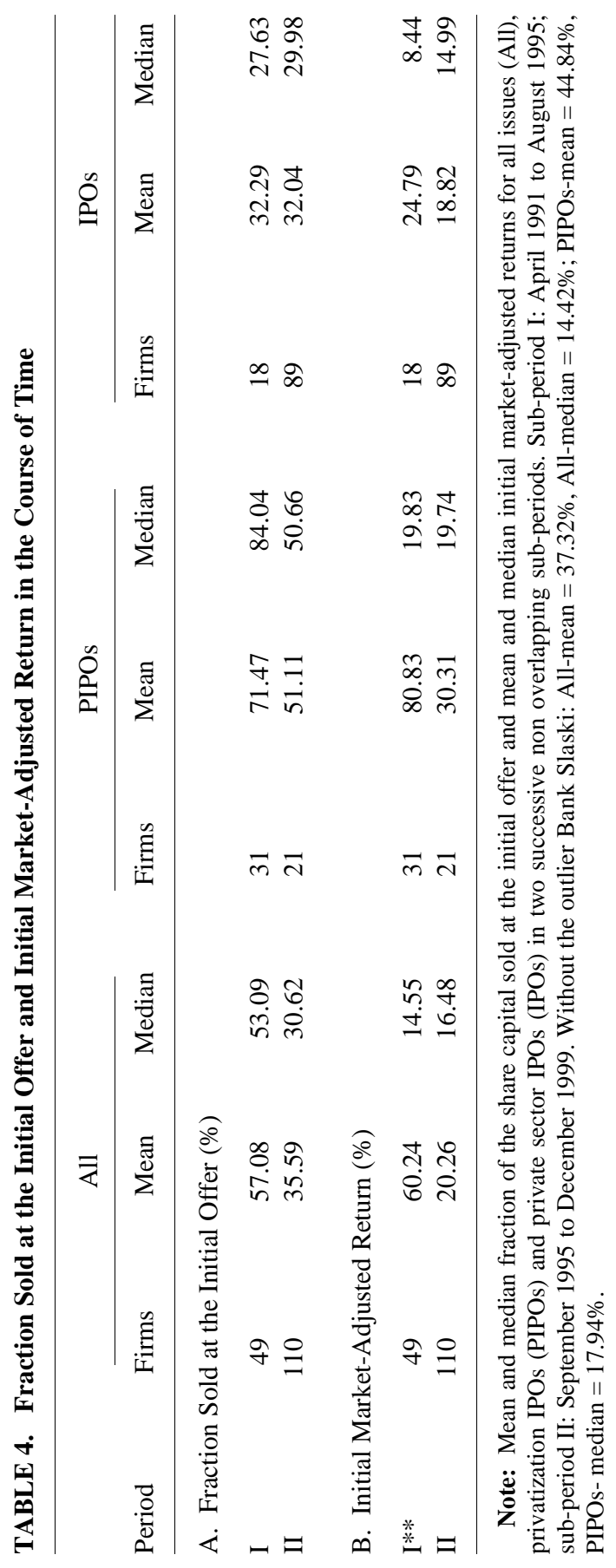


TABLE 5. Multivariate Cross-Sectional Regression Analysis

\begin{tabular}{|c|c|c|c|c|}
\hline & All & PIPOs & IPOs & $\begin{array}{l}\text { Hypothesis } \\
\text { (expected sign) }\end{array}$ \\
\hline \multirow[t]{2}{*}{ Intercept } & $-0.638^{*}$ & -1.469 & $-0.651 * *$ & \\
\hline & $(-2.60)$ & $(-1.97)$ & $(-2.32)$ & \\
\hline \multirow[t]{3}{*}{ SOLD } & $0.724 *$ & $1.065^{* *}$ & $0.718 *$ & $3(-)$ \\
\hline & $(3.90)$ & $(2.16)$ & $(2.88)$ & \\
\hline & {$[0.84]$} & {$[0.78]$} & {$[0.82]$} & \\
\hline \multirow[t]{3}{*}{ RETAIL } & $0.349 * *$ & $1.070 * *$ & 0.180 & $5(+)$ \\
\hline & $(2.34)$ & $(2.41)$ & $(1.34)$ & \\
\hline & [0.89] & {$[0.82]$} & {$[0.90]$} & \\
\hline \multirow[t]{3}{*}{ SIZE } & $0.089 * *$ & 0.134 & $0.120 * *$ & $2(-)$ \\
\hline & $(2.48)$ & $(1.74)$ & $(2.50)$ & \\
\hline & {$[0.86]$} & {$[0.74]$} & {$[0.87]$} & \\
\hline Adjusted $R^{2}$ & $8.7 \%$ & $9.2 \%$ & $7.0 \%$ & \\
\hline$F$-value & $5.960^{*}$ & $2.818 * *$ & $3.651 * *$ & \\
\hline Durbin-Watson & 1.86 & 1.82 & 2.10 & \\
\hline Number of firms ${ }^{\mathrm{c}}$ & 158 & 51 & 107 & \\
\hline
\end{tabular}

Note: Regression results for all issues (All), privatization IPOs (PIPOs) and private sector IPOs (IPOs). The tested multivariate regression is:

$$
I R_{i}=\alpha_{0}+\alpha_{1} S O L D_{i}+\alpha_{2} \text { RETAIL }_{i}+\alpha_{3} \operatorname{SIZE}_{i}+\varepsilon_{i}
$$

where $I R_{i}=$ initial market - adjusted return of issue $i ; S O L D_{i}=$ fraction of the share capital sold at the initial offer; $R E T A I L_{i}=$ relative portion domestic retail investors receive from the issue volume; $S I Z E_{i}=$ logarithmic market value of issue $i$ on the first trading day. Test statistics $(\cdot)$ and tolerance values $[\cdot]$ in parentheses. $*$ Significant at the $1 \%$ level. **Significant at the $5 \%$ level. ${ }^{\circ}$ The outlier Bank Slaski has been excluded from the sample all issues (All) and the sample privatizations (PIPOs).

value of issue $i$ on the first trading day (hypothesis 2: ex-ante uncertainty II).

Table 5 presents the regression results. ${ }^{15}$ First, the fraction of the share capital sold at the initial offer (variable SOLD) is significantly

15. Bank Slaski is viewed as an outlier and is therefore not included in the regression analysis. 
positively related to the initial market-adjusted return of Polish PIPOs and private sector IPOs. This result contrasts with hypothesis 3 (pure signaling) that high quality (=high initial market-adjusted return) firms sell less at the initial offer. Pure signaling models therefore do not apply for Polish PIPOs and their private sector counterparts. One interpretation of this result concerning PIPOs is that a higher political uncertainty might require selling a larger fraction to transfer control rights credibly. This in turn forces a committed government to underprice more, which results in a positive relationship between the initial market-adjusted return and the fraction sold.

Other studies relating the fraction of the share capital sold to the initial market-adjusted return of PIPOs include Jones et al. (1999) for an international sample of 93 PIPOs, Menyah and Paudyal (1996) for the UK and Paudyal, Saadouni, and Briston (1998) for Malaysian PIPOs. They report different findings. Paudyal, Saadouni, and Briston (1998) and Jones et al. (1999) document that a higher fraction sold is (significantly) related to higher initial market-adjusted returns. By contrast, Menyah and Paudyal (1996) find a significantly negative relationship for UK PIPOs.

Second, the initial market-adjusted return of Polish PIPOs is higher if a larger portion of the issue volume is allocated to domestic retail investors (variable RETAIL). This indicates that in order to attract citizens to buy shares an underpricing strategy is used. By contrast, the variable RETAIL has no explanatory power for private sector IPOs. This empirical evidence is in accordance with the model of Biais and Perotti (2000) and supports hypothesis 5 (re-election).

Finally, the initial market-adjusted return of PIPOs and private sector IPOs is positively related to firm size (variable SIZE). The larger the firm the higher the initial market-adjusted return. According to hypothesis 2 (ex-ante uncertainty II), smaller firms should experience a higher initial market-adjusted return because they are less known. The opposite is documented in Poland. The Polish government sold big and well-known state enterprises at a lower issue price. This is consistent with a government trying to generate support for its privatization program and is in line with a committed government (in contrast to a populist government).

To sum up, only one out of the three variables has the expected explanatory power for the initial market-adjusted return of Polish PIPOs: 
the portion of the issue volume sold to domestic retail investors. This supports the re-election hypothesis of Biais and Perotti (2000). The pure signaling hypothesis (hypothesis 3 ) as well as the ex-ante uncertainty hypothesis (hypothesis 2) have to be rejected. This applies to PIPOs as well as private sector IPOs.

\section{Test for Aftermarket Performance}

The objective of this section is to examine the aftermarket performance of firms going public on the WSE. Three hypotheses, specified in section 2, are explicitly tested: hypothesis 6 (no negative long-run performance for PIPOs), hypothesis 7 (PIPOs experience a better long-run performance than private sector IPOs) and hypothesis 8 (the long-run performance of PIPOs is positively associated with the fraction of the share capital sold).

\section{A. Methodology}

In order to measure the aftermarket performance of IPOs, buy-and-hold returns are calculated for each issue. The buy-and-hold return for issue $i\left(B H R_{i, T}\right)$ is defined as

$$
B H R_{i, T}=\prod_{t=2}^{T}\left(1+R_{i, t}\right)-1
$$

where $R_{i, t}$ is the return of IPO $i$ in period $t$ and $t=2$ indicates the second trading day in the aftermarket. ${ }^{16} \mathrm{BHR}$ s are calculated for the following time periods: $T=1$ week, 2 weeks, 1 year, 2 years and 3 years.

To be able to compare the aftermarket performance within the first three years after the first trading day for different time periods (for example one year and three years) only issues with a first trading day earlier than March $9^{\text {th }}, 1997$ are used. This leads to a reduction in the sample size to 83 firms for the sample of all issues, 38 firms for the sample of PIPOs and 45 firms for the sample of private sector IPOs.

16. The starting point for measuring the aftermarket performance is therefore the closing price on the first trading day. 
To measure the abnormal performance in the aftermarket it is first necessary to specify appropriate benchmarks. This task is of particular importance because it can affect the aftermarket performance measured. One possibility is to use a matching firm adjustment procedure, in which for each issuing firm a non-issuing firm of approximately similar size and the same industry is chosen. ${ }^{17}$ Another possibility, which is used for markets in which the number of potential benchmark firms is low, is to use one or more indices, for example the market index as a benchmark. ${ }^{18}$ Because of the low number of firms listed in the first years after the resumption of the WSE a matching procedure (for example matching by size and industry) is not possible in Poland. The aftermarket performance is therefore measured against the WIG-Index as a benchmark. For comparison purposes and as a robustness check an equally-weighted stock market index is used as an additional benchmark. ${ }^{19}$ To construct this index we are using all firms listed in the main and the parallel markets of the WSE.

In a similar way to (5) the $B H R$ of the WIG-Index for IPO $i$ $\left(B H R_{W I G, i, T}\right)$ is calculated as

$$
B H R_{W I G, i, T}=\prod_{t=2}^{T}\left(1+R_{W I G, i, t}\right)-1
$$

$R_{\text {WIG }, i, t}$ is the return of the WIG-Index in period $t$, where $t=2$ indicates the second trading day in the aftermarket. Therefore, buy-and-hold returns over identical intervals are calculated for each issue and the benchmark. To measure the market-adjusted performance, buy-and-hold abnormal returns (BHARs) and wealth relatives (WRs) are used. In accordance with Ritter (1991) the $W R$ of IPO $i\left(W R_{i, T}\right)$ is defined as

17. See for example Ritter (1991) or Loughran and Ritter (1995).

18. See for example Keloharju (1993) for the Finnish IPO market, Kunz and Aggarwal (1994) for the Swiss IPO market, Paudyal, Saadouni, and Briston (1998) for Malaysian and Jelic and Briston (1999) for Hungarian PIPOs and private sector IPOs.

19. It is common in the literature to use value-weighted as well as equally-weighted stock market indices as benchmarks (see for example Loughran and Ritter (1995) or Brav and Gompers (1997)). The WIG Index is a value-weighted index. Small PIPOs or private sector IPOs are therefore primarily compared with big firms. This is not the case when an equally-weighted index is used. 


$$
W R_{i, T}=\frac{1+B H R_{i, T}}{1+B H R_{W I G, i, T}}
$$

and BHARs are defined as

$$
B H A R_{i, T}=B H R_{i, T}-B H R_{W I G, i, T}
$$

Another important point in measuring the long-run abnormal performance of security prices is the use of appropriate test statistics. As the simulation results of Kothari and Warner (1997), Barber and Lyon (1997) and Lyon, Barber, and Tsai (1999) show, conventional tests of long-run abnormal security returns are often misspecified. They find that conventional parametric test statistics often indicate a long-run abnormal performance when none is present. They especially mention three main reasons for potential misspecifications: (a) survival-related biases, which occur if failing firms are excluded, (b) rebalancing biases, which arise if cumulative return procedures are used and (c) biases because long-run abnormal performance measures are typically skewed.

To minimize these sources of misspecification, this study includes all firms delisted on the WSE during the investigation period and uses buyand-hold returns to calculate the long-run performance. In addition, to account for the skewness bias, a skewness-adjusted $t$-statistic with bootstrapped p-values (as suggested by Lyon, Barber, and Tsai (1999)) and a non parametric Wilcoxon-Signed-Rank-Test are used to test the null hypothesis of no abnormal long-run performance. ${ }^{20}$

\section{B. Results}

Table 6 presents the aftermarket performance for the three samples. ${ }^{21}$ First, it can be seen that in line with the evidence of many other markets the short-run aftermarket performance (for the first two weeks) is not significantly different from zero. For the sample of all issues, for

20. As a result of their simulation analyses concerning the long-run security price performance, Kothari and Warner (1997) recommend using non-parametric and bootstrap tests to reduce misspecifications.

21. The results of using the equally-weighted market index are not shown as they do not change the main conclusions. 


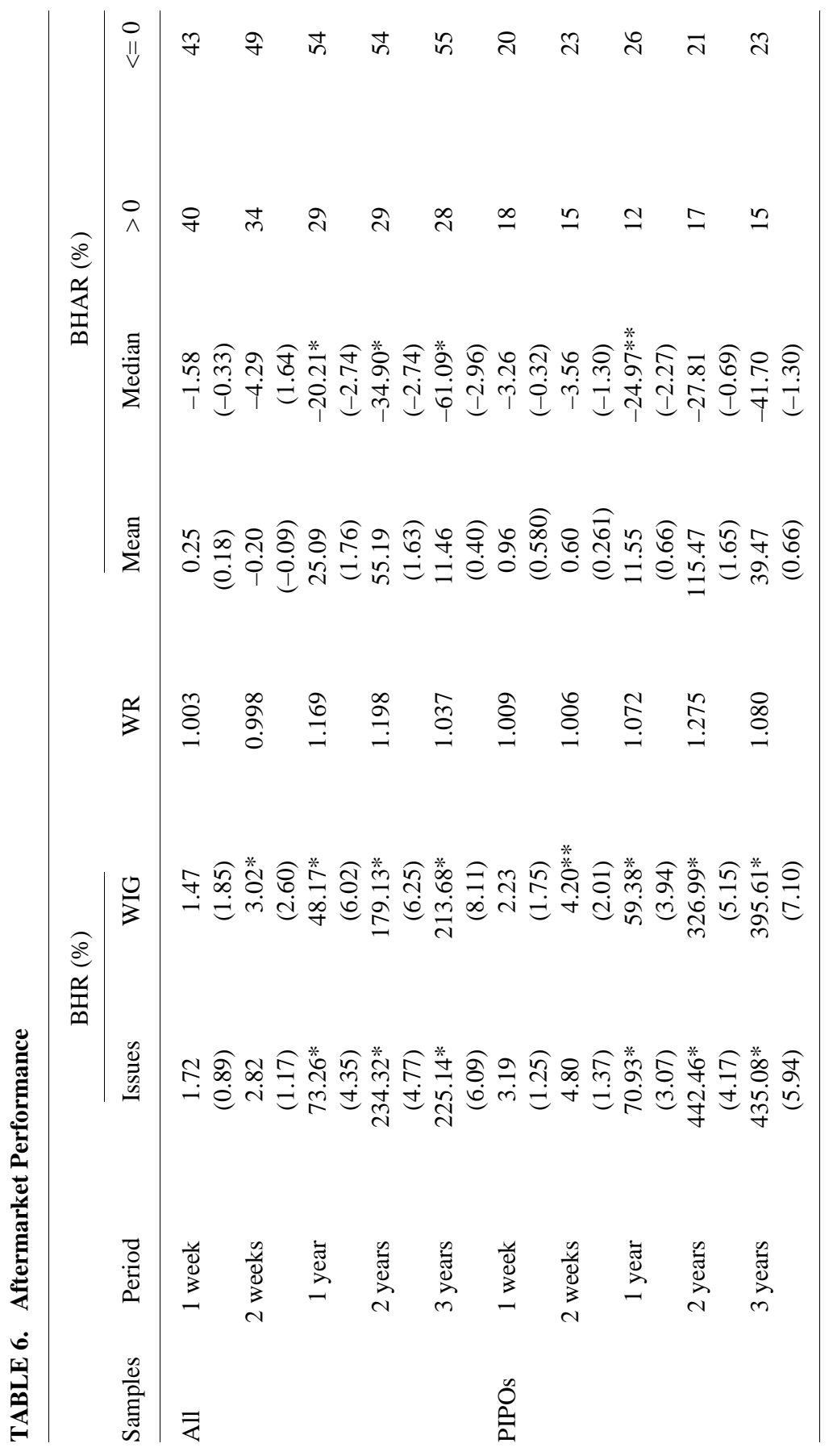




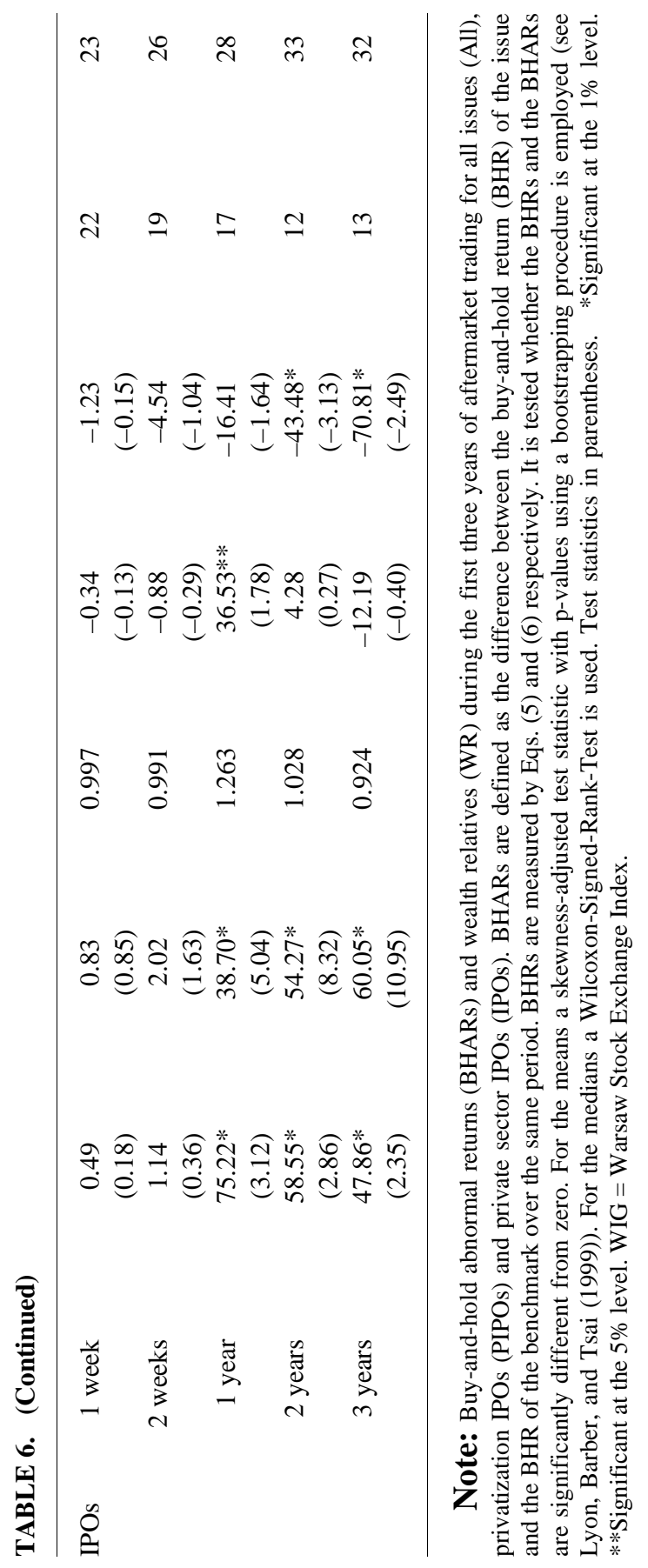


instance, the average BHAR over the first two weeks is -. $2 \%$. A nonnegative short-run aftermarket performance can also be observed for PIPOs and private sector IPOs, respectively. This result leads to the conclusion that for Polish PIPOs as well as private sector IPOs there is full price adjustment on the first trading day. ${ }^{22}$

The long-run aftermarket performance for the first three years reveals some differences between the samples. For the sample of all issues the average (median) BHAR is $+11.5 \%(-61.1 \%)$ and the wealth relative is 1.037 (see table 6). The negative median-BHAR is significantly different from zero at the $1 \%$-level. More than $66 \%$ of all issues experience a negative long-run performance (55 out of 83 ). The 3-year abnormal performance of PIPOs is a bit better: The mean-BHAR is positive $(+39.5 \%)$, but the median-BHAR is negative $(-41.7 \%)$. Both values are not significantly different from zero at conventional significance levels. Hypothesis 6 can therefore be accepted. According to the model of Perotti (1995) it could be expected that a marketoriented government trying to build up reputation over time is not interested in a significantly negative long-run performance of PIPOs. The non-negative long-run performance of Polish PIPOs is evidence for a market-oriented government.

These findings for Polish PIPOs are in contrast to the international evidence found by Megginson et al. (2000). For a 33-country sample of 117 PIPOs they document a significantly positive aftermarket performance for the first three years against national indices as benchmarks. Jelic and Briston (1999) also report a significantly positive abnormal performance for a sample of 16 Hungarian PIPOs till the third-year anniversary of public trading. The evidence for Polish PIPOs is in line with a non-significant 3-year abnormal performance documented in Paudyal, Saadouni, and Briston (1998) for Malaysian PIPOs and in Boubakri and Cosset (1999) for a 26-country sample of 120 PIPOs when they adjust for market effects.

PIPOs yield a highly significant mean unadjusted 3-year return of $+435.1 \%$. This is nearly four times higher than the average $B H R$ Boubakri and Cosset (1999) document for their sample of developing countries. The annual average return (geometric mean) for Polish

22. Similar results are documented for Hungary (see Jelic and Briston (1999)) and Malaysia (see Paudyal, Saadouni, and Briston (1998)). 
PIPOs corresponds to $74.9 \%$.

Private sector IPOs experience an insignificant average performance over the first three years: The mean-BHAR is $-12.2 \%$ (see table 6). But the mean is associated with a significantly negative median-BHAR of $-70.8 \%$. For 32 out of 45 private sector IPOs the 3-year BHAR is negative. Polish private sector IPOs therefore tend to underperform in the long-run but the evidence is not unambiguous. ${ }^{23}$ In contrast, a clearly negative and significant 3-year abnormal performance is documented by Jelic and Briston (1999) for a sample of 12 Hungarian private sector IPOs.

Hypothesis 7 predicts that Polish PIPOs experience a better long-run (abnormal) performance than their private sector counterparts. Panel A of table 7 reveals that hypothesis 7 has to be rejected. The 3-year abnormal performance difference (difference in the BHARs) is slightly positive but insignificant. ${ }^{24,25}$ This evidence for Poland is in line with the findings for Malaysia (see Paudyal, Saadouni, and Briston (1998)) but contradicts the evidence for Hungary. Jelic and Briston (1999) report a significantly positive performance difference between PIPOs and private sector IPOs.

To test whether the fraction of the share capital sold at the initial offer has an influence on the long-run performance, the samples of PIPOs and private sector IPOs are each divided into two groups: a group with a large fraction sold (i.e. above the median) and a group with a low fraction sold (i.e. below the median). Panel B of table 7 summarizes the results. State enterprises of which the government sells a large fraction at the initial offer experience a positive 3 -year abnormal performance of $+86.9 \%$ whereas for enterprises of which only a small fraction is sold the average $B H A R$ is $-8.0 \%$. The difference measured by average and median $B H A R$ is not, however, significant. If an equality-weighted index is used as benchmark, the mean and median$B H A R$ differences are not significant either. Hypothesis 8 is, therefore, rejected. The fraction sold at the initial offer has no influence on the

23. The main conclusions do not change when an equally-weighted market index is used as benchmark.

24. Similar results for Poland are provided by Jelic and Briston (2000).

25. The results do not change when an equally-weighted market index is used as benchmark. 
TABLE 7. Test for Differences in the Long-Run Aftermarket Performance

A. Difference between PIPOs and IPOs (PIPOs minus IPOs).

\begin{tabular}{|c|c|c|c|c|}
\hline \multirow[b]{2}{*}{ Period } & \multicolumn{2}{|c|}{ BHR (\%) } & \multicolumn{2}{|c|}{ BHAR $(\%)$} \\
\hline & Issues & WIG & Mean & Median \\
\hline \multirow[t]{2}{*}{1 year } & -4.29 & 20.69 & -24.98 & -8.56 \\
\hline & $(-0.09)$ & $(0.82)$ & $(0.74)$ & $(-0.59)$ \\
\hline \multirow[t]{2}{*}{2 years } & $383.91 * *$ & $272.72 *$ & 111.20 & 15.67 \\
\hline & (2.30) & (3.06) & (1.09) & $(0.92)$ \\
\hline \multirow[t]{2}{*}{3 years } & $387.22 *$ & $335.56 *$ & 51.66 & 29.11 \\
\hline & (3.73) & (4.83) & $(0.74)$ & $(0.23)$ \\
\hline
\end{tabular}

B. 3-Year BHARs (\%) - Large Fraction (LARGE) versus Small Fraction (SMALL) of the Share Capital Sold.

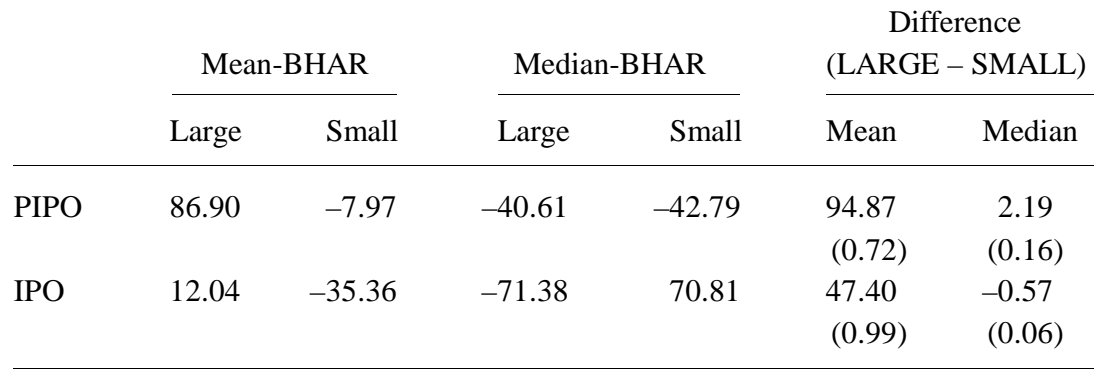

Note: Panel A: Mean and median differences between privatized companies (PIPOs) and private sector IPOs (PIPOs minus IPOs) for buy-and-hold returns (BHRs) and buy-andhold abnormal returns (BHARs). Panel B: Comparison of the 3-year BHAR for issues of which a large or a small fraction of the share capital is sold at the initial offer. Values above the median are defined as large and values below the median as small. In panel A and panel $\mathrm{B}$ it is tested whether (i) the differences in the mean and (ii) the differences in the median values are significantly different from zero. For the means a $t$-test and for the medians a Wilcoxon-Signed-Rank-Test is used. Test statistics in parentheses. * Significant at the $1 \%$ level. **Significant at the $5 \%$ level.

long-run performance of private sector IPOs either. This evidence is consistent with the findings by Paudyal, Saadouni, and Briston (1998) for private sector IPOs in Malaysia. 


\section{Summary}

This article examines the characteristics and the short- and long-run price behavior of two groups of firms going public in Poland: privatization initial public offerings (PIPOs) and private sector IPOs. Unlike other Central and Eastern European countries (for example Russia, the Czech Republic or Slovakia) Poland did not start its privatization process with a mass privatization program. Instead the Polish government privatized many firms through public offerings on a case-by-case basis.

On average, Polish PIPOs as well as private sector IPOs are significantly underpriced. With a mean of $60 \%$ the initial market-adjusted return of PIPOs is above the initial market-adjusted return of private sector IPOs. The difference is not, however, statistically significant and can partly be explained by the huge initial market-adjusted return of Bank Slaski. In comparison to the international evidence provided in Jones et al. (1999), the Polish government sold a higher fraction of the share capital at the initial offer and underpriced more than the average government in the world did. This observation is consistent with a committed government according to Perotti (1995).

A multivariate cross-sectional analysis reveals that the initial marketadjusted return is significantly higher when the government allocates a large portion of the issue volume to domestic retail investors. This evidence is in line with the re-election hypothesis of Biais and Perotti (2000). By contrast, pure signaling models are not able to explain the initial market-adjusted return of Polish PIPOs and private sector IPOs.

The long-run performance provides interesting results: First, Polish PIPOs neither under- nor overperform benchmarks over the first three years of aftermarket trading. This is in contrast to Megginson et al. (2000), who document a significantly positive long-run performance for a 33-country sample of PIPOs, but is in line with the observations of Boubakri and Cosset (1999) for a 26-country sample of PIPOs and of Paudyal, Saadouni, and Briston (1998) for Malaysian PIPOs. The nonnegative long-run performance of Polish PIPOs is consistent with a market-oriented government trying to build up reputation for its privatization program in the course of time.

Second, the long-run abnormal performance of Polish PIPOs and private sector IPOs is not significantly different from each other. Third, the fraction of the share capital sold at the initial offer has no influence 
on the long-run performance of Polish PIPOs. A lower (direct) political influence is therefore not associated with a better long-run performance.

\section{References}

Aggarwal, R.; Leal R.; and Hernandez, L. 1993. The aftermarket performance of initial public offerings in Latin America. Financial Management (Spring): 42-53.

Allen, F., and Faulhaber, G. R. 1989. Signaling by underpricing in the IPO market. Journal of Financial Economics 23: 303-323.

Barber, B. M., and Lyon, J. D. 1997. Detecting long-run abnormal stock returns: The empirical power and specification of test statistics. Journal of Financial Economics 43: 341-372.

Biais, B., and Perotti, E. C. 2000. Machiavellian privatization. Working paper. Toulouse: Universite des Sciences Sociales de Toulouse, and Amsterdam: University of Amsterdam.

Boubakri, N., and Cosset, J.C. 1999. The aftermarket performance of privatization offerings in developing countries. Working paper. Montreal: Ecole des HEC.

Boycko, M.; Shleifer, A.; and Vishny, R. W. 1996. A theory of privatization. Economic Journal 106 (March): 309-319.

Brav, A., and Gompers, P. A. 1997. Myth or reality? The long-run underperformance of initial public offerings: Evidence from venture and nonventure capital-backed companies. Journal of Finance 52: 1791-1821.

Dewenter, K. L., and Malatesta, P. H. 1997. Public offerings of state-owned and privately-owned enterprises: An international comparison. Journal of Finance 52: 1659-1679.

Grinblatt, M., and Hwang, C. Y. 1989. Signaling and the pricing of new issues. Journal of Finance 44 (June): 393-420.

Huang, Q., and Levich, R. M. 1998. Underpricing of new equity offerings by privatized firms: An international test. Working paper. New York: Hofstra University and New York University.

Jelic, R., and Briston, R. 1999. Hungarian privatization strategy and financial performance of privatized companies. Journal of Business Finance \& Accounting 26: 1319-1357.

Jelic, R., and Briston, R. 2000. Privatization initial public offerings: The Polish experience. Working paper. Birmingham: University of Birmingham, and Hull: University of Hull.

Jenkinson, T., and Mayer, C. 1988. The privatization process in France and the UK. European Economic Review 32: 482-490.

Jones, S. L.; Megginson, W. L.; Nash, R. C.; and Netter, J. M. 1999. Share issue privatizations as financial means to political and economic ends. Journal of 
Financial Economics 53: 217-253.

Keloharju, M. 1993. The winner's curse, legal liability, and the long-run price performance of initial public offerings in Finland. Journal of Financial Economics 34: 251-277.

Kothari, S. P., and Warner, J. B. 1997. Measuring long-horizon security price performance. Journal of Financial Economics 43: 301-339.

Kunz, R. M., and Aggarwal, R. 1994. Why initial public offerings are underpriced: Evidence from Switzerland. Journal of Banking and Finance 18: 705-723.

Levis, M. 1993. The long-run performance of initial public offerings: The UK experience 1980 - 1988. Financial Management 22: 22-41.

Loughran, T., and Ritter, J. R. 1995. The new issues puzzle. Journal of Finance 50 (March): 23-51.

Loughran, T.; Ritter, J. R.; and Rydqvist, K. 1994. Initial public offerings: International insights. Pacific-Basin Finance Journal 2: 165-199.

Lyon, J. D.; Barber, B. M.; and Tsai, C.-L. 1999. Improved methods for tests of long-run abnormal stock returns. Journal of Finance 54 (February): 165-201.

Megginson, W. L.; Nash, R. C.; and Van Randenborgh, M. 1994. The financial and operating performance of newly privatized firms: An international empirical analysis. Journal of Finance 49 (June): 403-452.

Megginson, W. L.; Nash, R. C.; Netter, J. M.; and Schwartz, A. L. 2000. The long-run return to investors in share issue privatizations. Financial Management 29 (Spring): 67-77.

Megginson, W. L., and Netter, J. M. 2000. From state to market: A survey of empirical studies on privatization. Working paper. Norman: University of Oklahoma, and Athens: University of Georgia.

Menyah, K., and Paudyal, K. 1996. Share issue privatizations: The UK experience. In M. Levis (ed). Empirical Issues in Raising Equity Capital: 17-48. Amsterdam: Elsevier.

Paudyal, K.; Saadouni, B.; and Briston, R. J. 1998. Privatization initial public offerings in Malaysia: Initial premium and long-term performance. PacificBasin Finance Journal 6: 427-451.

Perotti, E. C. 1995. Credible privatization. American Economic Review 85 (September): 847-859.

Perotti, E. C., and Guney, S. E. 1993. The structure of privatization plans. Financial Management 22: 84-98.

Ritter, J. R. 1991. The long-run performance of initial public offerings. Journal of Finance 46 (March): 3-27.

Su, D., and Fleisher, B. M. 1999. An empirical investigation of underpricing in Chinese IPOs. Pacific-Basin Finance Journal 7: 173-202.

Welch, I. 1989. Seasoned offerings, imitation costs, and the underpricing of initial public offerings. Journal of Finance 44 (June): 421-449. 